\title{
ON SOME COPEPODA FROM PLYMOUTH, MAINLY ASSOCIATED WITH INVERTE- BRATES, INCLUDING THREE NEW SPECIES
}

\author{
By R. U. GoodING \\ From the Plymouth Laboratory ${ }^{1}$
}

(Text-figs. I-6)

Work on copepods at the Plymouth Marine Laboratory in 1954-55 revealed some new species and some which have been described but whose occurrence in that region had not previously been reported. Specimens from both these categories are discussed in the present paper.

The names of copepods associated with the fish of the region are comparatively well known through the work of Bassett-Smith, Leigh-Sharpe and others (although the present record for Peniculus fistula suggests that the list is still incomplete; and others might bear re-investigation); but little attention has been paid to invertebrates as hosts. Norman \& Scott (1906) and LeighSharpe's paper on the Herpyllobiids (I926) together formed the basis of the I93I Plymouth Fauna list for records of species associated with these animals; and additions have later been made in the following papers: Gray (I933), Gurney (1933), Atkins (1934), and Leigh-Sharpe (1933). These references, in conjunction with the present publication, indicate that the invertebrate fauna of Plymouth is probably as prolific a source of associated copepods as any.

My sincere thanks are due to Dr J. P. Harding, under whom this work was done, and to Dr Paul Illg in particular for reading this paper and for giving me the benefit of so detailed and constructive a criticism; to the Director for facilities at the Marine Laboratory, Plymouth, and for constant encouragement; to the members of the Staffs of that Laboratory and this Department for help, host specimens and advice at the times I needed them most; and, finally, to the Government of Barbados, B.W.I., for allowing me to apply funds from a I950 Scholarship to this study.

\section{DEFINITIONS}

The word 'associated' has been used in the title and throughout this paper because it is felt that terms like 'parasitic', 'semi-parasitic', 'commensal',

1 Present address: Zoology Department, University of Washington, Seattle, U.S.A. 
etc., should be restricted to cases where there is some definite evidence about the nature of the association, and little work to this end has been done on the Copepoda (cf. especially Baer, 195I; Gotto, 1954). Symbiosis, in its widest sense (Allee, Emerson, Park, Park \& Schmidt, I949; Davenport, I955; etc.), is perhaps broad enough for use in this context, but the term adopted has the advantage of simplicity and is unlikely to cause confusion through previous usage in a stricter sense. There seems no need for formal definition except to say that, in the Copepoda, it is intended to include the range from forms firmly attached to a single host, usually of a particular species, to those with as free-and-easy a host requirement as some lichomolgids; and may be applied equally to the earlier instars, if they are found in contact with the host, as to adults. But it still seems necessary to distinguish between the partners in the association: I suggest that the concept of 'host' is already wide enough, and that 'associate' should here refer to the copepod.

Several terms have from time to time been used to differentiate the regions of the copepod body, some purely descriptive, others borrowed to express opinions on comparative crustacean morphology. I am adopting, for descriptive work, those introduced by Sars (I90I), but, in addition, have added 'cephalothorax' - for use in a restricted sense-and proposed 'prosome' - as antithetic to 'urosome'- to include both 'cephalosome' and 'metasome'. (There seem definite advantages in retaining Sars's original meanings for these terms in preference to Wilson's, 1932, p. 9, interpretation.) These regions may now be defined:

Prosome: the anterior region of the body, commonly limited posteriorly by a major articulation;

Cephalosome: the head region when this includes only the somite of the maxillipedes;

Cephalothorax: the head region including, in addition to the maxillipedal somite, pedigerous segments in a fused complex;

Metasome: those free thoracic segments in front of the major articulation; Urosome: that part of the body behind the major articulation.

This terminology is applicable to all divisions of the Copepoda despite the fact that, for instance, in the Calanoida, the urosome may include only the genital and succeeding segments, while in some Caligoida it contains all segments behind the third pedigerous; but it is hoped that the division of the body into two main parts will facilitate description especially in the Cyclopoida, where the anterior region is usually sharply defined from the posterior by a considerable difference in width.

The homology of the poecilostome mouthparts has also been a source of some discussion: whether the same number as is present in other groups may here be distinguished or, if not, which is lacking. Lang (1946a) has discussed the arguments but, despite his conclusion-partly modified in 1948 
(p. 24)-I shall presume that a mandible, maxillule, maxilla, and maxilliped can be identified in the two new poecilostomes described here. Also, although it now seems generally agreed that the somite bearing the maxillipedes is the first thoracic segment (permanently included in the head region), I have tried to avoid confusion by using the terms 'pedigerous' instead of 'thoracic', when discussing the somites bearing the thoracic legs as a whole, or that of the fifth leg by itself, and 'prosomal' to refer to those bearing legs one to four. In the descriptions of many appendages, 'articulated process' denotes both setae and spines (for a summary of the differences between these see Gurney, I93I, p. 38), 'process' being restricted to the usual carcinological connotation of an unarticulated projection.

The following is a list of abbreviations which have been used in referring to the swimming legs:

$$
\begin{aligned}
& \text { P I, P2, etc.-first, second, etc., pairs; } \\
& \text { basp.-basipodal segments; } \\
& \text { (basp. I-coxa; basp. 2-basipodite); } \\
& \text { end.-inner ramus (endopodite); } \\
& \text { exp.-outer ramus (exopodite); } \\
& \text { Si-inner border of segments; } \\
& \text { St-terminal border of segments; } \\
& \text { Se-outer border of segments. }
\end{aligned}
$$

I have followed Sewell (I949) in differentiating the spines by Roman, the setae by Arabic numerals.

\section{METHODS}

Collection methods are dealt with under the individual records.

Much of the examination, and all measurements and drawings (for which a camera lucida was used) were made from preparations cleared and mounted temporarily, in lactic acid. (I am very grateful to Dr Harding for suggesting this method.) Whole specimens were mounted in a 'hanging drop' to avoid compression by the cover-slip. For measuring, the specimens were oriented dorsal surface uppermost; and the length taken from the rostrum to the end of the caudal rami (not including the caudal setae).

\section{CYCLOPOIDA: SIPHONOSTOMA}

Family MicropontIIDAE nov.

Only one genus, Micropontius, is at present known.

\section{MICROPONTIUS gen.nov.}

The characters of the type and only species will serve to define this genus. 


\section{Micropontius ovoides sp.nov.}

Specimens examined. (I) Numerous adult females, several with ovisacs, and males in magnesium chloride washings (cf. pp. 203-4) from Spatangus purpureus, O. F. Müller, trawled or dredged on the Looe-Eddystone and Eddystone Shell Gravel Grounds near Plymouth, March-June 1955. (2) Rather fewer of these from Echinocardium cordatum (Pennant), E. pennatifidum Norman and E. flavescens (O. F. Müller), similarly collected, mainly obtained from the Bigbury Bay and Looe-Eddystone Grounds during the above period. (3) One female from a Brissopsis lyrifera (Forbes), dredged I5 miles south of Penmarche Lighthouse (off Concarneau, east coast of France), depth about 53 fathoms; 23 May 1955.

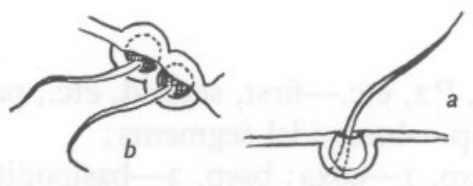

Fig. I. Detail of the setae on the prosome of Micropontius ovoides (semi-diagrammatic). $a$, a view from the side showing the integumental cup, with its narrow opening, and the seta extending to the bottom; $b$, surface view: the ventro-lateral ridge of the segment can be seen to extend as a hood over the outer part of the pit.

Type specimens. The holotype, an adult female, and paratypes, including males and ovigerous females, all selected from the first category above, have been deposited at the British Museum (Natural History). The generic name refers both to size and affinities, the specific to shape.

\section{Description of the female}

The ovigerous female is nearly elliptical in outline; a specimen without ovisacs appears somewhat spade-shaped in dorsal view; both nearly twice as long as wide (Fig. $2 a$ ).

The prosome occupies much the greater part of the body area. The cephalothorax includes the first pedigerous segment, whose anterior limit is indicated only by a thickened strip dorsally and, in part, laterally. There are three metasomal segments, the dorsal articulations of which are also thickened. The postero-lateral corners of all the prosomal segments are produced backward for a short distance into a sharp point; and the posterior border of the third pedigerous is extended to form an 'apron', with a thickened distal edge, which covers the urosome in dorsal view as far as the insertion of the caudal rami. The tergites of the segments bearing the second and third pairs of

\section{Legend to Fig. 2}

Fig. 2. Micropontius ovoides, gen. et sp.nov., adult female. a, dorsal view (an ovisac and parts of the body, which would otherwise have been obscured, are represented by broken lines in this and other figures); $b$, side view; $c$, antennule; $d$, antenna; $e$, maxilla; $f$, maxilliped; $g$, first swimming leg; $h$, abnormal third endopod segment of first leg; $i$, second swimming leg; $j$, third swimming leg; $k$, fourth swimming leg; $l$, fifth leg; $m$, urosome (detail is shown on one side only). 


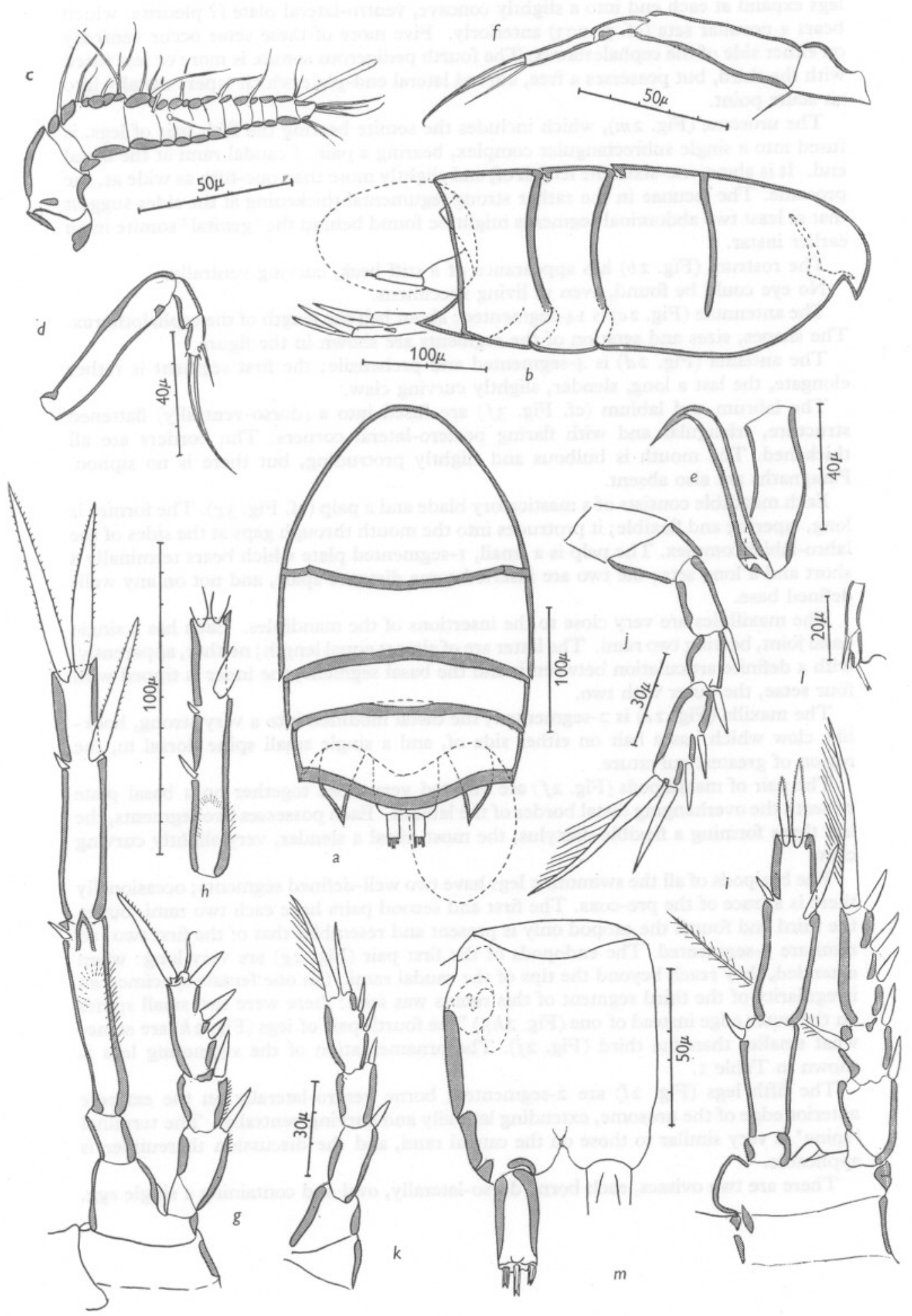

Fig. 2 
legs expand at each end into a slightly concave, ventro-lateral plate (? pleurite) which bears a peculiar seta (cf. p. 203) anteriorly. Five more of these setae occur ventrally on either side of the cephalothorax. The fourth pedigerous somite is more or less fused with the third, but possesses a free, curved lateral end-plate which tapers distally into an acute point.

The urosome (Fig. $2 \mathrm{~m}$ ), which includes the somite bearing the fifth pair of legs, is fused into a single subrectangular complex, bearing a pair of caudal rami at the distal end. It is about one-sixth the length of, and slightly more than one-fifth as wide as, the prosome. The lacunae in the rather strong tegumental thickening at the sides suggest that at least two abdominal segments might be found behind the 'genital' somite in an earlier instar.

The rostrum (Fig. $2 b$ ) has appearance of a stiff beak, curving ventrally.

No eye could be found, even in living specimens.

The antennule (Fig. $2 c$ ) is I4-segmented; about half the length of the cephalothorax. The shapes, sizes and setation of the segments are shown in the figure.

The antenna (Fig. $2 d$ ) is 4 -segmented and prehensile; the first segment is rather elongate, the last a long, slender, slightly curving claw.

The labrum and labium (cf. Fig. $3 f$ ) are fused into a (dorso-ventrally) flattened structure, triangular and with flaring postero-lateral corners. The borders are all thickened. The mouth is bulbous and slightly protruding, but there is no siphon. Paragnaths are also absent.

Each mandible consists of a masticatory blade and a palp (cf. Fig. $3 g$ ). The former is long, tapering and flexible; it protrudes into the mouth through gaps at the sides of the labro-labial complex. The palp is a small, I-segmented plate which bears terminally a short and a long seta; the two are inserted some distance apart, and not on any welldefined base.

The maxillules are very close to the insertions of the mandibles. Each has a single basal joint, bearing two rami. The latter are of almost equal length; neither, apparently, with a definite articulation between it and the basal segment; the inner is tipped with four setae, the outer with two.

The maxilla (Fig. $2 e$ ) is 2 -segmented; the distal modified into a very strong, hooklike claw which has a hair on either side of, and a single small spine dorsal to, the region of greatest curvature.

The pair of maxillipeds (Fig. $2 f$ ) are inserted very close together on a basal plate beneath the overhanging distal border of the labium. Each possesses five segments, the last three forming a flexible dactylus, the most distal a slender, very slightly curving claw.

The basipods of all the swimming legs have two well-defined segments; occasionally there is a trace of the pre-coxa. The first and second pairs have each two rami, but in the third and fourth the exopod only is present and resembles that of the first two; all rami are 3-segmented. The endopods of the first pair (Fig. $2 g$ ) are very long: when extended, they reach beyond the tips of the caudal rami. (In one female specimen an irregularity of the third segment of this ramus was seen: there were two small spines on the outer edge instead of one (Fig. $2 h$ ).) The fourth pair of legs (Fig. $2 k$ ) are somewhat smaller than the third (Fig. $2 j$ ). The ornamentation of the swimming legs is shown in Table I.

The fifth legs (Fig. $2 l$ ) are 2-segmented, borne ventro-laterally on the extreme anterior edge of the urosome, extending laterally and curving ventrally. The terminal 'spine' is very similar to those on the caudal rami, and the discussion thereunder is applicable.

There are two ovisacs, each borne dorso-laterally, oval and containing a single egg. 
The caudal rami (Fig. $2 \mathrm{~m}$ ) are cylindrical, nearly three times as long as wide, and armed terminally - at least in preserved specimens - with three (or occasionally four) short, stout 'spines'. In some specimens which were examined alive and immediately after capture, however, these appeared to be very fine setae about half as long as the urosome; and, if this is the case, they must break during fixing and manipulation.

TABLE 1. ORNAMENTATION OF THE SWIMMING LEGS OF MICROPONTIUS OVOIDES SP.NOV.

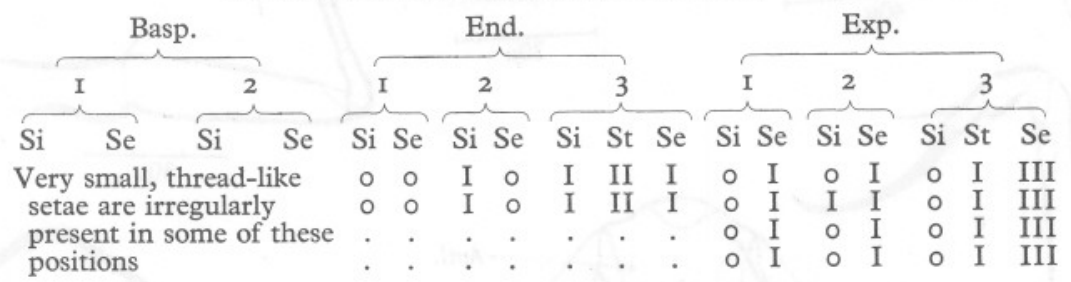

\section{Description of the male}

As for the female, except that the body (Fig. $3 a-c$ ) is an almost perfect ellipse in outline. There is no major articulation, the urosome being firmly fused to the prosome.

The second metasomal segment has no 'apron' projection on its distal edge; the lateral end-plates of the third are fused, near the base to the framework strengthening the insertion of the urosome and more posteriorly to the urosome itself; the two are joined dorsally by a chitinous membrane whose posterior edge is thickened and also fused to the urosome.

The urosome (Fig. $3 a, b$ ) is much wider and more rounded, with a strongly thickened framework. There is no hint of segmentation.

The antennule (Fig. $3 d$ ) is 13 -segmented and doubly geniculate (between the fourth and fifth, and eleventh-twelfth segments). The aesthetasc, on the last segment, is unusually stout.

All the swimming legs (Fig. $3 j-m$ ) are a little smaller in proportion.

The fifth legs (Fig. $3 n$ ) are borne ventrally near the middle of the extreme anterior edge, and thus very difficult to distinguish except in a carefully dissected specimen.

A pair of sixth legs are occasionally represented, in well-preserved specimens, by a single small seta at each distal corner of the spermatophoral apparatus.

The caudal rami are inserted rather more ventrally than those of the female (but still visible in dorsal view), and are much shorter.

\section{Dimensions}

Female-length $0.39 \mathrm{~mm}$; width $0.22 \mathrm{~mm}$. Male-length $0.35 \mathrm{~mm}$; width $0.21 \mathrm{~mm}$.

\section{Colour}

This is variable: some specimens exhibiting a reddish tinge, others more or less colourless. The internal organs and ovisacs are usually opaque white to cream coloured; the first arranged so as to leave a clear circular area on either side of the cephalothorax. Occasionally, purplish fragments can be seen in the intestine.

\section{Morphological notes}

Three points concerning the external morphology of this species deserve further comment. The first of these is the structure of the extreme posterior 
R. U. GOODING

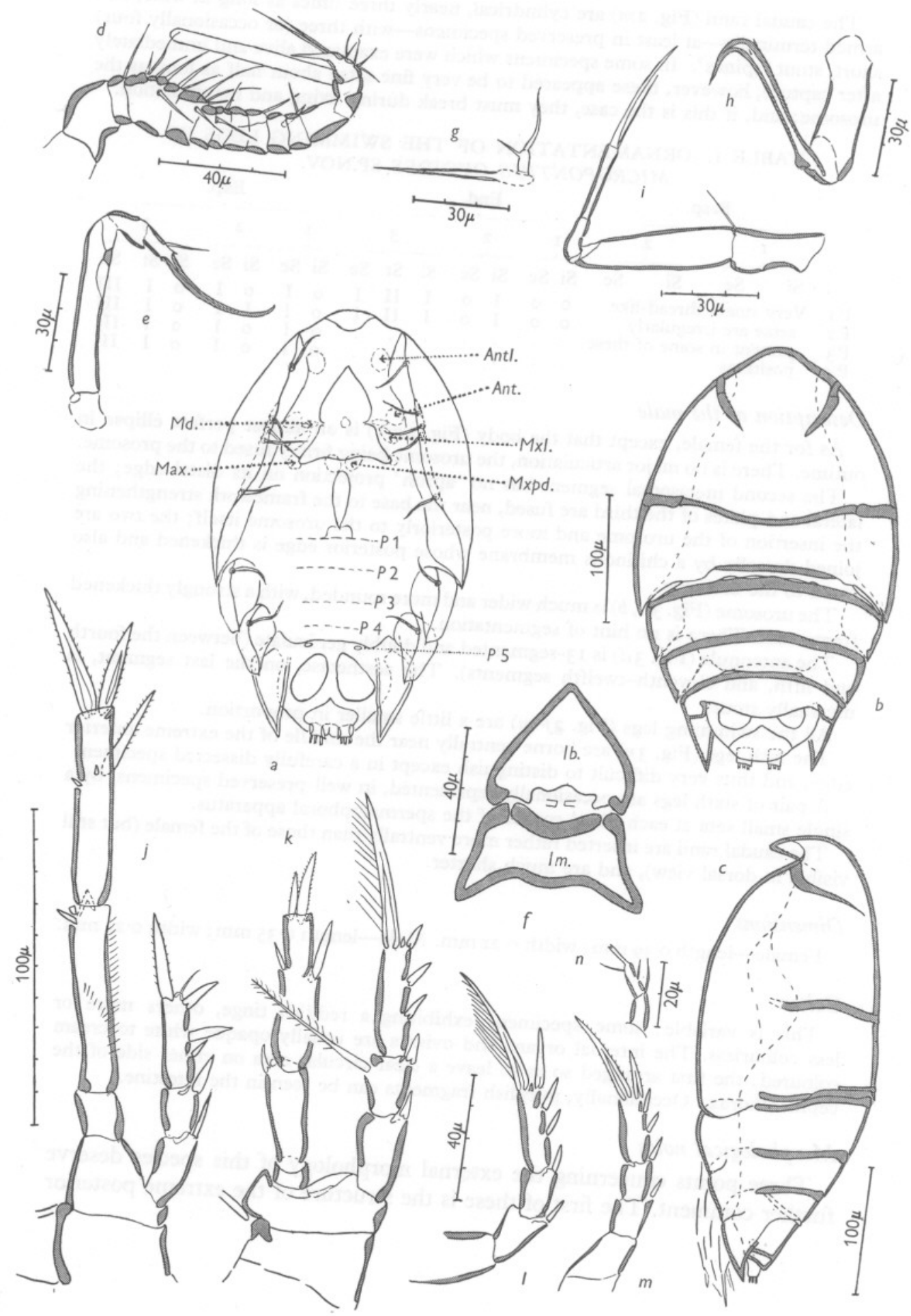

Fig. 3 
part of the body in the female. That this forms a very efficient means of providing support and some degree of protection for the ovisacs may be seen by a comparison of Fig. $2 a$ and $b$. The first pair of legs are normally carried fully extended, so that their endopods reach backwards as far as do the ovisacs and support these. The latter are separated dorsally by a prominence just under the distal margin of the 'apron' (cf. Fig. $2 b$ ), and rather more ventrally by the urosome itself; while the 'apron', both dorsally and laterally, helps to keep them in place.

The second concerns the arrangement of the setae on the ventro-lateral margins of the prosome (Fig. $3 a$ ). The base of each seta is enclosed in a pit with thick chitinous walls. These pits may often be rather less regular than depicted in both shape and construction-especially in the male, and are situated on the inner side of the ventro-lateral ridge of the segment which continues as a hood over the outer part of the pit, restricting movement of the base of the seta to the shaded portion in Fig. $\mathrm{I} b$. The setae themselves are very long and flexible, and are not plumose. It seems very probable that they have a sensory function though no movement of them could be detected in specimens examined alive. In any case they appear to be unique in structure and position in the Copepoda.

The final note is also related to structures which are probably sensory in function. These have the appearance, in the living specimen, of long, threadlike hairs, but usually form papilla-like projections when preserved. Like the spines on the caudal rami and fifth legs, this may be due to the hardening and subsequent breaking. They are scattered over the exterior of the body, including the rostrum, but are much more frequent on the dorsal and lateral surfaces. Similar structures have been noted while examining specimens of other species, and they are probably present on the majority of, if not all, copepods, being easily overlooked unless the body is minutely examined.

Micropontius ovoides can easily be recognized by a combination of the following characters: body shape and size; arrangement of the pro- and urosomes; lack of the endopods to the third and fourth pairs of swimming legs, and the ornamentation of all the latter; the peculiar setae on the ventral surface; and the mouth shield (labro-labial complex).

\section{Biology}

This species (and the other echinoid associates) was obtained by a slight modification of Bocquet's (1952) method; the host was left in a dry dish for

\section{Legend to Fig. 3}

Fig. 3. Micropontius ovoides, gen. et sp.nov., adult male. a, ventral view, to show where the appendages are inserted (Antl., antennule; Ant., antenna; Max., maxilla; $M d$., mandible; $M x l$., maxillule; $M x p d$., maxilliped; $P_{1}$, first, $P_{2}$, second, etc., pairs of legs); $b$, dorsal view; $c$, side view; $d$, antennule; $e$, antenna; $f$, mouth complex (lb., labrum; $l m$., labium); $g$, the mandible, the basal part is shown by broken line since its extent is not easy to see; $h$, maxilla; $i$, maxilliped; $j$, first swimming leg; $k$, second swimming leg; $l$, third swimming leg; $m$, fourth swimming leg; $n$, fifth swimming leg. 
about half an hour, and then sufficient magnesium chloride solution added to cover it completely. (This was the usual $7 \frac{1}{2} \%$ solution in fresh water, diluted approximately by half with filtered sea-water; application for a short time seems to anaesthetize most copepods, with the exception of certain harpacticoids). After a period of some $15 \mathrm{~min}$, the liquid was filtered off through fine netting - tied over the nozzle of a large funnel-and the residue washed into a small dish with Plymouth filtered 'outside' sea-water (to avoid introducing extraneous species). The copepods were picked out from this under a binocular dissecting microscope (several were always found trapped in the surface film from which they could be dislodged only with difficulty) and transferred to a dish of clean water, where they recovered rapidly and could be kept alive for some time.

These copepods were found only on the spatangids listed above (p. I98), but no experiments were done on host specificity. That Spatangus purpureus is the definitive host at Plymouth is suggested not only by the fact that every one examined over a period of 3 months yielded at least ten, and usually forty or more, Micropontius ovoides while specimens of the species of Echinocardium never had more than four and were often free from these copepods; but, more particularly, by the following instance: six Spatangus purpureus, trawled inside the Eddystone Shell Gravel on I9 May I955, yielded 289 specimens; an Echinocardium pennatifidum, from the same haul and brought in in the same jar, had only two. The water in the jar in this case was also filtered, since it had not proved possible to obtain bottom samples from the Spatangus ground for testing to see whether the copepods were confined to the echinoids or generally distributed throughout the substratum, and sixteen specimens were found: most of these proved either dead or moribund.

It is possible, however, that this 'host specificity' may have a correlation with some physical factor, such as particle size of the substrate, Spatangusat Plymouth-preferring a coarse sand and Echinocardium spp. a rather more muddy bottom. In this connexion, a Spatangus raschi Loven (dredged about I 50 miles west of Ushant- $48^{\circ} 05^{\prime}$ N., $08^{\circ} \mathrm{II}^{\prime} \mathrm{W}$.- -in 220 fathoms, Io April I955, and kindly identified by Mr George Nicholls, Museum of Zoology and Comparative Anatomy, Oxford) is interesting since, though it was in excellent condition, no copepods were obtained from it; the bottom in this case was a very fine, thick, black mud, with numerous stones. The specimen from Brissopsis (bottom marked on chart as 'soft sand, grey mud') is valuable in extending the known distribution of Micropontius ovoides, but it cannot be considered an accurate estimate of abundance since the echinoderms were all dead when examined.

To give some idea of the relative abundance of the sexes, a sample from Spatangus, obtained on I9 May 1955, was analysed: the 289 specimens included I 88 females, of which 46 were ovigerous, and ror males. No other complete 
analysis was done, but it is the author's impression that this proportion is about average. The fact that adults are relatively numerous, while only one egg, rather large in proportion to its parents, is ever found in each ovisac, suggests an efficient means of infection and/or a short larval life. Although it was not possible to obtain a satisfactory figure or description of the form which hatches from the egg, it can be stated that this is a perfectly normal siphonostome first naupliar stage, suggesting that if development is abbreviated it must be in the later stages. At no time was anything resembling a late instar found, despite a particularly careful search (since this might have done much to clear up the systematic position of the species).

Careful observations, under magnification ( $\times 24$ to roo) made on more than one occasion on hosts which were later proved to be infected, also failed to show any Micropontius in situ; but with creatures so small and inconspicuous, in addition to the difficulties of observing a spatangid under such magnification, this cannot be taken as definite proof that the body surface is not their natural habitat. No satisfactory method was devised to test the other hypothesis: that they live in the alimentary or body cavities and move out when the host is dried and immersed in magnesium chloride.

\section{Behaviour in laboratory}

Micropontius ovoides usually remains relatively immobile on the bottom of the dish, occasionally working its mouthparts or making quick jerks with its swimming legs. It always comes to rest on its back, and seems unable to swim off from this position.

When a spatangid spine is introduced, however, and the creature manoeuvred until it has grasped this, it becomes rather more active. The antennae and maxillipeds are used both to grip the spine and to keep the body clear of it; the swimming legs are held close to the body surface; the antennules usually at right angles to the body and above the substrate. Occasionally, when at rest, the aesthetasc is used, apparently to palpate the spine. When 'walking', the antennae and maxillipeds move in a typically quadripedal succession, and the creature may scurry up and down the spine quite rapidly.

Attempts to dislodge a specimen from a spine, for example by gentle nudges with a needle, may produce any of four responses: scuttling away to another part of the spine; 'freezing', in which the body is pressed close to the spine, the maxillae probably (this could not be observed) being used to provide greater gripping power; transference to the needle point; or an 'annoyance' reaction, when the animal swims up and away from the spine with rapid jerks of its swimming legs and then sinks motionless until it lies on the bottom, ventral surface uppermost. Since the creature seems unable to swim off except from some support, it is possible that the long endopods of the first legs, with or without assistance from the antennae or maxillipeds, are used to give a 'shove off'. 
Specimens pipetted on to a living Spatangus and observed under a binocular dissecting microscope did not behave in any way differently from that described above. Most remained holding on where they fell—occasionally, if they were on a spine, moving up or down it-and exhibiting the usual reactions when touched with a needle. None ever left the host, or swam to a different spine, or, when near the mouth, attempted to enter this.

\section{Systematics}

The systematic position of the new genus Micropontius is doubtful. It is certainly siphonostome, and, as the Siphonostoma stand at present, it possesses many characters which suggest relationship with the Dyspontiidae and Asterocheridae. As Nicholls (1944, pp. 15-16) points out, the former is not a very well-defined family; and there are several anomalous genera, such as Stephopontius Thompson \& Scott (referred by Sewell, 1949, p. 167, to ? Cancerillidae), which he does not include in it but which exhibit certain resemblances both to the Dyspontiidae and to this new genus. My opinion is that Micropontius is sufficiently distinct to be separated, for the present, as the type of a new family, the Micropontiidae, but, since a future (and much needed) revision of the Siphonostoma may uncover possible evolutionary lines into which it will fit, I have decided not to expand this idea further in the present paper.

Family AsTEROCHERIDAE Giesbrecht, I899 (sens. strict.) Asterocheres violaceus (Claus, I889)

Occurrence. Numerous adult males and females were found in magnesium chloride washings of Echinus esculentus L., obtained from various localities in the region, throughout the year. Specimens averaged about fifty per host; with a sex ratio of nearly two females to every male. Instars from 'Copepodid II' (i.e. an immature specimen with three pairs of legs and the rudiments of a fourth) to adult occurred rather rarely in March and April 1955 .

Distribution. North Sea to Mediterranean; adults (? and stages) typically associated with camarodont echinoids, but occasionally with asteroids or free from a host.

Notes. I have followed Giesbrecht (I899) in regarding the genus Echinocheres Claus as a synonym of Asterocheres Boeck, since the distinction between them seems too slight to justify retention of the former. In support of this view, it may be mentioned that in my specimens, as in those of A. Scott (in Herdman \& Scott, 1896) - which both Giesbrecht (1899) and Sars (1913-I8) agree in referring to this species-the mandibular palp was distinctly 2-jointed and the fifth pair of legs in the female ciliated on both sides; this appears to leave only the lengths of the siphon and maxillular setae-surely characters of specific rather than generic importance? 
Family Dyspontindae Sars, I915

Scottomyzon gibberum (T. \& A. Scott, 1894)

Occurrence. One male was found in a jar containing Spatangus purpureus Müll., dredged inside the Eddystone Shell Gravel Grounds, I9 April I955.

Distribution. Norway to English Channel; adults typically found associated with Asterias rubens L.

Notes. Several $A$. rubens were searched at various times throughout the year, but the 'loges irrégulières' mentioned by Bocquet (1952) were not found, nor did washings from the surface yield any of these copepods.

\section{CYCLOPOIDA: POECILOSTOMA}

\section{Family Lichomolgidae Kossmann, I877}

\section{Lichomolgus leptodermatus sp.nov.}

Specimens examined. Several males and females (most of the latter ovigerous) from the gills of a single Laevicardium crassum (Gmelin) trawled on the Looe-Eddystone- 'Two-in-one' Grounds, 8 March 1955.

Type specimens. The holotype (an adult female) and several paratypes (both males and females), all cleared in lactic acid have been deposited at the British Museum (Natural History).

\section{Description of the female}

The body shape (Fig. 4a) is cyclopoid, nearly three times as long as wide; urosome about equal in length to the prosome, one-third its width.

The prosome is oval in dorsal outline, nearly one and a half times as long as broad; slightly inflated. The dorsal plates of the prosomal segments are separated laterally, and rounded at the corners. The cephalothorax includes the first pedigerous segment, the line of fusion being indicated by a groove dorsally and laterally.

The urosome is 5-segmented, though there is a flexible intersegmental region between the genital and fifth pedigerous segments. The genital is the widest segment in the urosome, and is divided dorsally (but not ventrally) by a distinct line; it is spindleshaped. The succeeding abdominal segments are all alike in size.

A spoon-shaped rostrum (Fig. $4 b$ ) is present, which extends forward and down, and is not prehensile.

There is also an eye.

In the 7-segmented antennule (Fig. 4c), the articulation between the third and fourth segments is indistinct. There are not very many setae, and the representation of these in the figure is approximate only, since, even when stained, they are very difficult to make out. No aesthetasc could be seen.

The antenna (Fig. $4 d$ ) is 4 -segmented, the third being small and indistinctly defined. The appendage is weakly prehensile, the terminal segment tipped with a curved and jointed claw and two weaker but unjointed ones, the inner the longest.

The labium is inflated and cone-shaped (in lateral, anterior and ventral views). The posterior edge has a deep, even groove down the mid-line.

No paragnaths could be found. 


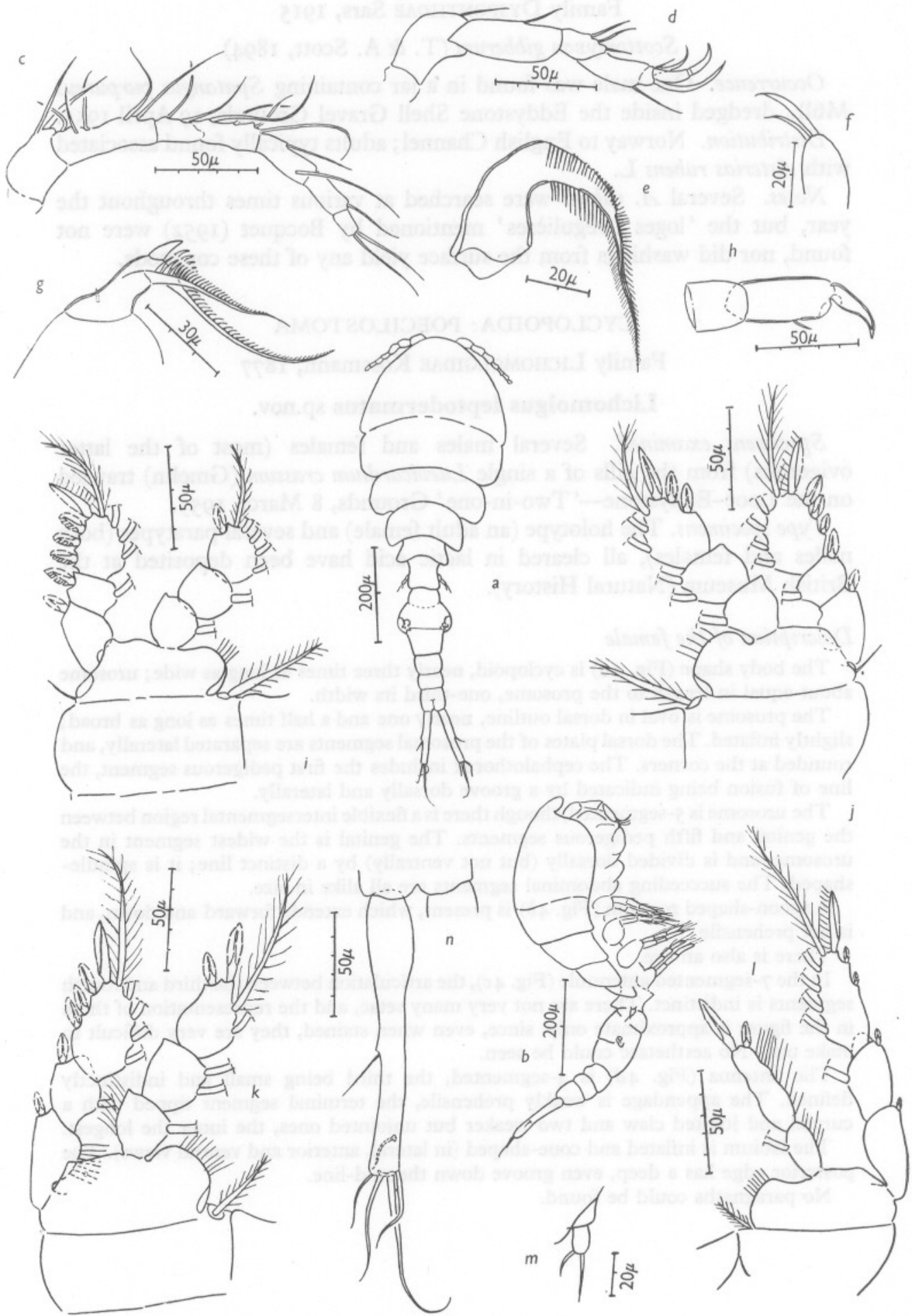

Fig. 4 
The labium is so indistinctly defined that no details of size, shape or texture could be made out.

The mandible (Fig. $4 e$ ) is of the usual lichomolgid type, with a single long, tapering lappet which is finely spinose on either edge; none of these spinules is enlarged.

There is a small, palp-like maxillule (Fig. $4 f$ ) with two rather stout terminal setae of differing lengths.

The basal segments of the 2-segmented maxilla (Fig. $4 g$ ) is rather short and inflated. The distal has a terminal, seta-like blade which is spinose-the spinules becoming longer and stronger towards the base, the proximal one very stout-on the inner edge only; and a shorter, but otherwise very similar, accessory blade borne a short distance towards the 'outside' (considering the part in situ). There is a small spine near the base of the segment.

The maxilliped (Fig. $4 h$ ) is also 2-segmented, with a strong complex attachment to the framework of the head. The first segment is rather long, with a small seta on the inner side; the last modified into a stout, but not very strong, claw.

The swimming legs (Fig. $4 i-l$ ) have each a basipod of two segments, and two rami, all 3 -segmented except the endopod of the fourth legs which has two only. Their ornamentation is illustrated in the figures mentioned above, and summarized in Table 2.

\section{TABLE 2. ORNAMENTATION OF THE SWIMMING LEGS OF LICHOMOLGUS LEPTODERMATUS SP.NOV.}

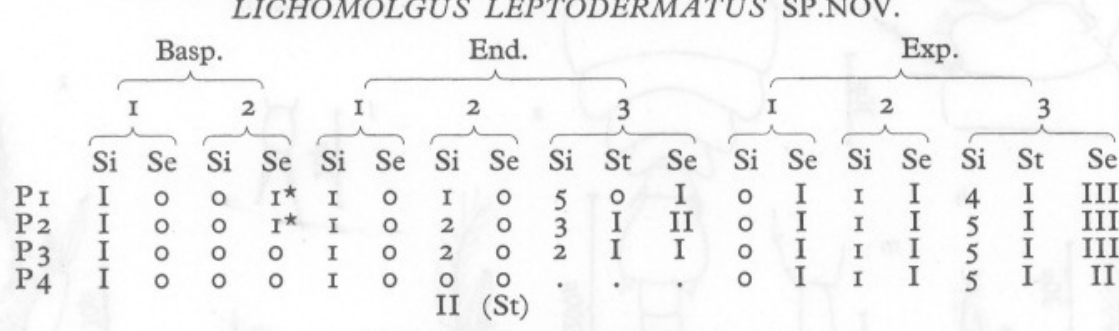

* This may occasionally be absent.

The fifth pair of legs (Fig. $4 \mathrm{~m}$ ) are very small; 2-segmented, the basal fused with but sharply defined from, the thoracic somite, and borne midway along this. There is no seta on the basal segment, but two terminally on the distal, the inner shorter and thicker.

A small seta and a curving spine laterally near the middle of the genital segment represent all that could be seen of the sixth legs.

The caudal rami (Fig. $4 n$ ) are very elongate, about as long as the post-genital segments together, and eight or nine times as long as wide. There is an outer-edge seta just in the distal half, and four terminal ones-the longest only five-eighths the length of the ramus, none setose-and a small dorsal seta near the distal border.

\section{Legend to Fig. 4}

Fig. 4. Lichomolgus leptodermatus, sp.nov., adult female. $a$, dorsal view; $b$, side view; $c$, antennule; $d$, antenna; $e$, mandible; $f$, maxillule; $g$, maxilla; $h$, maxilliped; $i$, first swimming leg; $j$, second swimming leg; $k$, third swimming leg; $l$, fourth swimming leg; $m$, fifth leg; $n$, dorsal view of the left caudal ramus. 

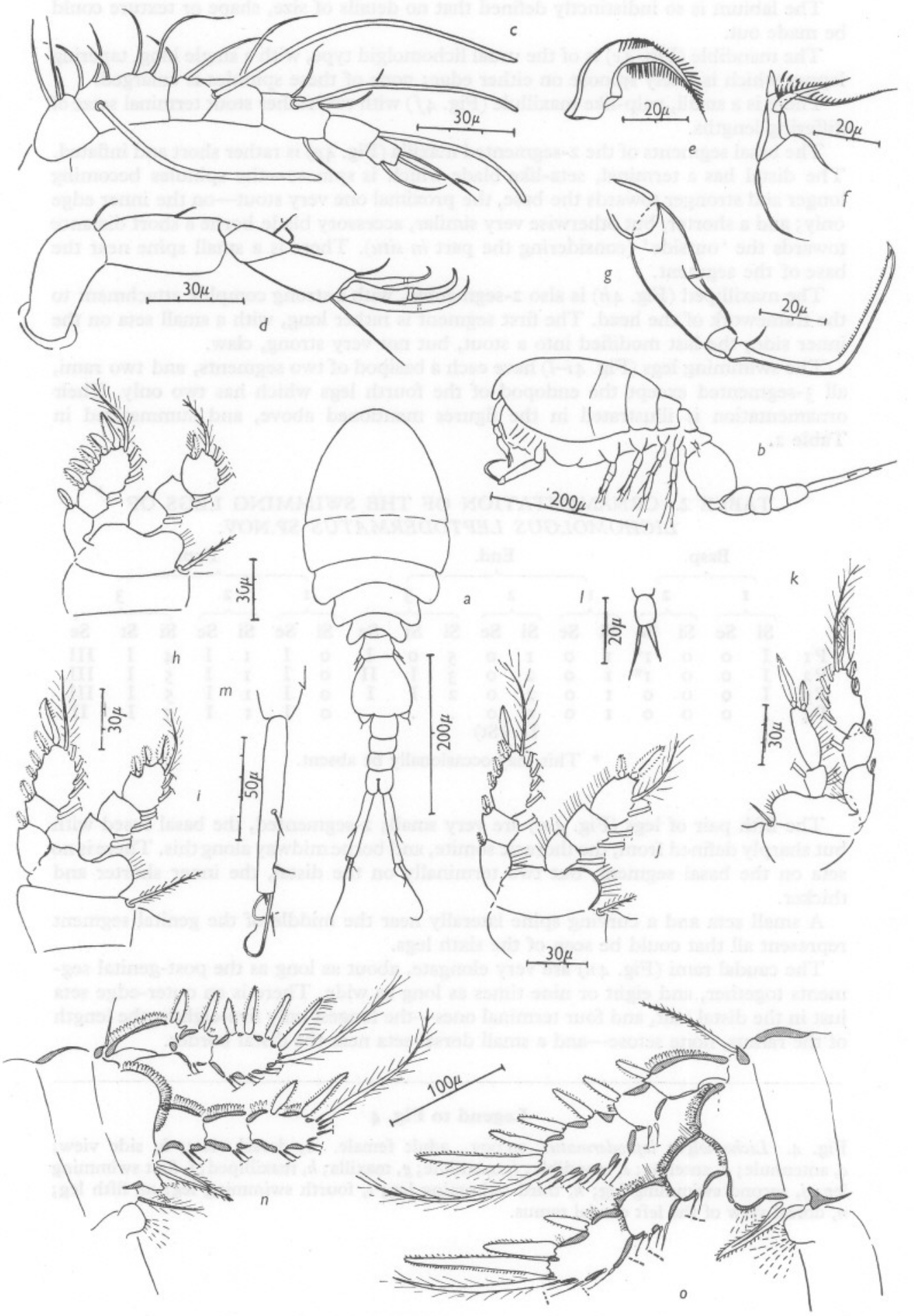

Fig. 5 


\section{Description of the male}

As for the female, except the body shape (Fig. $5 a$ ) is slightly more elongate-more than three times as long as wide. This is due, in great measure, to a lengthening of the prosome, so that the urosome attains more than one-third the width of this. The junction of the first pedigerous segment with the rest of the cephalothorax is not very well-defined.

The urosome is 6-segmented, with no intersegmental region; it is four times as long as wide. The genital segment broadens from front to rear, and is undivided.

The antennule (Fig. $5 c$ ) has an aesthetasc on each of the second, fourth, fifth and sixth segments.

All three terminal claws of the antenna (Fig. $5 d$ ) are jointed, but this is less clear in the outer and inner ones.

The mouthparts (Fig. $5 e-f$ ) have a slightly stronger integument.

Of the three free segments of the maxilliped (Fig. 5 g), the last is a very long, narrow claw, bent in the centre almost into a right-angle, the distal half with a row of very fine hairs on the inner side; there is a short seta near the base of this segment.

The setae on the outer side of the second basipod segment, present in the first and second pairs of swimming legs in the female, may be lacking.

The sixth pair of legs are represented by a single small seta on each postero-lateral corner of the genital segment; these appear in dorsal view to be borne on a small mammiform projection.

\section{Dimensions}

Female, length $0.90 \mathrm{~mm}$, greatest width $0.33 \mathrm{~mm}$. Male, length $0.59 \mathrm{~mm}$, width $0.19 \mathrm{~mm}$.

\section{Colour}

Colourless and transparent except for the ovary, ovisacs and testes which were opaque by transmitted, and white (in the case of the first two) or pale rose by reflected light; and the ruby-red, shining eye.

\section{Morphological notes}

A most noticeable feature of the living animal was the posture of the body. Even when swimming freely, this was bent sharply between the fourth and fifth pedigerous segments (the major articulation) and again between the genital and succeeding abdominal segments-roughly like a ' $Z$ ' ' which had been pulled out at either end until the angles between the parts were obtuse. (An attempt to show this has been made in Fig. $5 b$ but the original drawing was made on a lactic acid-cleared specimen, in which the exoskeleton was too flexible to hold its original shape, and this necessitated some alterations to obtain the desired effect.)

\section{Legend to Fig. 5}

Fig. 5. $a-m$. Lichomolgus leptodermatus, sp.nov., adult male. $a$, dorsal view; $b$, side view; $c$, antennule; $d$, antenna; $e$, mandible; $f$, maxilla; $g$, maxilliped; $h$, first swimming leg; $i$, second swimming leg; $j$, third swimming leg; $k$, fourth swimming leg; $l$, fifth leg; $m$, side view of caudal ramus. $n-o$. Conchyliurus cardii, sp.nov., adult female. $n$, first swimming leg; $o$, second swimming leg. 


\section{Systematics}

The nearest attempt at a key to the genus Lichomolgus Thorell is to be found in Sewell's (1949, pp. 93-94) analysis of the setal formulae in the various species. L. leptodermatus represents a variation of that author's 'final stage of reduction', since the suppression of spines has extended to the third pair of swimming legs where one has been lost on the terminal segment, not of the exopod, but of the endopod.

In addition, the following characters appear to be distinctive, either separately or in conjunction: the very large proximal spine on the main lappet of the maxilla; the proportions of the caudal rami and their setae; the terminal armature of the antenna; the dactylus of the male maxilliped; and the very thin exoskeleton. It will be seen that the species does show a resemblance to L. albens Thorell.

\section{Biology}

The specimens were all found in small swellings of the gill tissues of the host. Each of these 'cysts' contained usually one male and one female, but as many as two females and three males did occur together. Both the large and small gills were infected, and these on either side (the swellings showing up clearly as whitish spots against the pink of the gill tissue); but neither the mantle nor the labial palps yielded any; nor were any seen swimming in water taken from the mantle cavity.

No movement could be detected in specimens lying in these swellings but, when they were released, there was a brief initial period of intense activity, usually terminating when the creature came to rest on surface of the gill. The males were, as usual, more active than the females. In a dish, this alternation of periods of activity with long quiescent phases-provided no sudden external stimulus was applied-persisted; under these conditions, too, ovigerous females soon shed their ovisacs.

Some of the specimens collected must have been in the last copepodid stage since cast skins were found in a culture which had been kept overnight; but these moult stages proved too delicate for manipulation and no immature specimens were found on subsequent re-examination. Infection of Laevicardium may take place in one of the later copepodid stages, as a careful search of the gills failed to discover any early instars.

\section{Pseudanthessius liber (Brady \& Robertson, I875)}

Occurrence. This species was found several times, but only in small numbers (one or two per host), together with Asterocheres violaceus in washings from the surface of Echinus esculentus, January and February 1955.

Distribution. Coasts of Norway, British Isles and Channel, Indian Ocean; adults typically associated with camarodont echinoids, but occasionally taken from other invertebrates or not associated. 


\section{Family Clausididdae Embleton, I90I \\ Conchyliurus cardii sp.nov.}

Specimens examined. Eight females-two samples of three and five respectively-all ovigerous, were found in jars containing Cardium (Acanthocardia) echinatum Linn. dredged in Bigbury Bay, near Plymouth; 23 May 1955 and 6 July 1955.

Type specimens. Holo- and paratypes have been deposited in the British Museum (Natural History). The specific name refers to the host.

\section{Description of the female}

The body (Fig. $6 a$ ) is rather more elongate than the typical cyclopoid form; and strongly built. The prosome is little expanded, its dorsal outline forming an ellipse (truncated posteriorly), whose long axis would be (if not truncated) about twice the short. The greatest width is in the region of the first pedigerous segment; this somite is included in the cephalothorax; and there is no trace of a line of fusion between it and the rest of the 'head' region. The cephalothorax occupies about half the prosomal area. There is a band of very fine spinules just outside its ventro-lateral border. The lengths of the three metasomal segments are about equal; the postero-lateral corners of the first two and the cephalothorax appear slightly produced and pointed in dorsal (or ventral) view.

The urosome is 5-segmented, with a flexible intersegmental region between the fifth pedigerous and the genital segments. (This has the appearance of another somite, and is marked off with equal distinctness from both the foregoing. It is probably, however, part of the fifth pedigerous segment: the integument is not thickened as it is in the other urosomal segments, and in dead specimens the body is usually bent sharply at this point, cf. Fig. $6 b$ ). The segment bearing the fifth pair of legs is rather narrower than that preceding it, and not very long. The genital segment is the widest in the urosome, but slightly longer than wide. It is structurally very complex, and more material will be necessary before all the details can be satisfactorily elucidated. The anal segment is equal in length to the two preceding abdominal somites, and has a row of very fine teeth ventrally near the proximal end and similarly on the distal border. The widths of these three abdominal segments decrease evenly from front to rear.

The rostrum (Fig. $6 c$ ) is rather well-developed; it is visible in dorsal or ventral view rather than lateral (where it tends to be concealed by the antennules), and apparently non-mobile.

There is a double kidney-shaped eye, which can be seen in the living animal to have a shining spot (? lens) on the anterior end of either side.

The antennule (Fig. $6 d$ ) extends only about half the length of the cephalothorax. It is 6-segmented; the relative lengths, widths and armature of the segments are shown in the figure, and there are aesthetascs on the fifth and seventh segments.

The antenna (Fig. $6 e$ ) is a strongly prehensile, 4-segmented structure, with a large claw on the penultimate segment and seven articulated processes terminally. The surfaces of the segments are covered with patches of denticles, some small and spine-like, others-especially on the second and third segments-larger and more robust. In addition to the claw on the distal corner of the third segment, there is a small toothed projection near whose base a short seta is borne. The terminal segment is, as usual in the Clausidiids, somewhat offset. 
R. U. GOODING
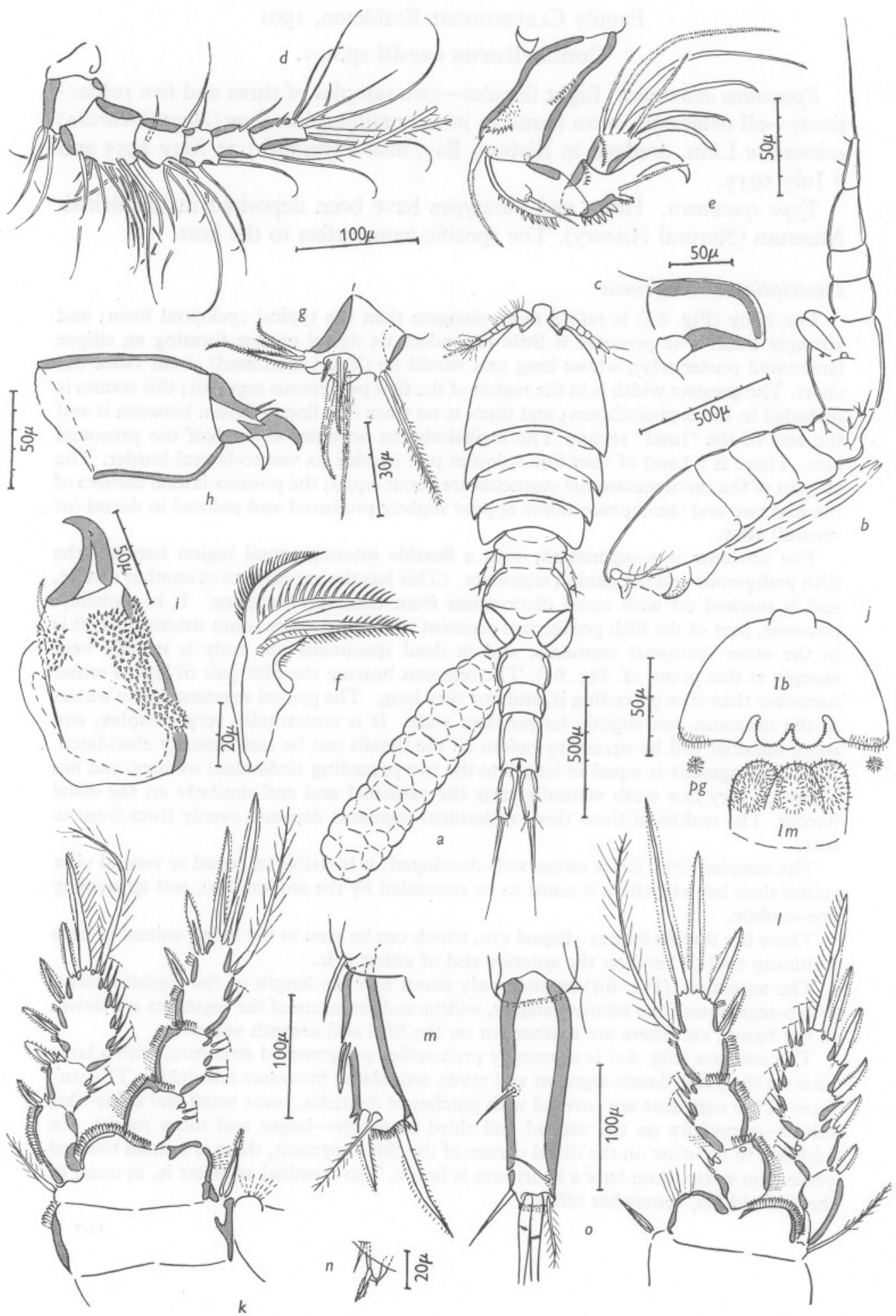

Fig. 6 
The mouthparts are all very closely appressed to each other. The labrum (Fig. $6 j$ ) has a sinuate posterior margin, beneath which are two small serrate lobes, one on either side of the mid-line. The paragnaths are rudimentary, being represented by small ciliated projections between the mandibles and maxillae. A small, indistinct, spinose structure, with two grooves dividing it into three aproximately equal lobes represented all that could be identified as the labium.

The mandible (Fig. $6 f$ ) has three lappets, almost equally elongate although the fact that the two upper ones are usually curved makes the lowest seem longer; these are all borne on a thickened base, the innermost partly joined to a prominence. The middle lappet is coarsely setose, the others more finely.

The maxillule (Fig. $6 \mathrm{~g}$ ) consists of a single free segment, partly bi-lobed. Its shape and ornamentation are as illustrated.

The maxilla (Fig. $6 h$ ) is 2-segmented; the first large and easily seen in ventral view: the second is modified into a very strong, stout, curved claw which bears two smaller claws, one on the concave surface and the other to one side, usually projecting above the large claw. The first segment has no ornamentation.

TABLE 3. ORNAMENTATION OF THE SWIMMING LEGS OF CONCHYLIURUS CARDII SP.NOV.

\begin{tabular}{|c|c|c|c|c|c|c|c|c|c|c|c|c|c|c|c|c|c|}
\hline \multicolumn{4}{|c|}{ Basp. } & \multicolumn{7}{|c|}{ End. } & \multicolumn{6}{|c|}{ Exp. } & \\
\hline & & & & 1 & & 2 & & & 3 & & & & & 2 & & 3 & \\
\hline $\mathrm{Si}$ & $\mathrm{Se}$ & $\mathrm{Si}$ & $\mathrm{Se}$ & $\mathrm{Si}$ & $\mathrm{Se}$ & $\mathrm{Si}$ & $\mathrm{Se}$ & $\mathrm{Si}$ & St & $\mathrm{Se}$ & $\mathrm{Si}$ & $\mathrm{Se}$ & $\mathrm{Si}$ & $\mathrm{Se}$ & $\mathrm{Si}$ & St & $\mathrm{Se}$ \\
\hline I & 0 & I & I & I & 0 & I & 0 & 2 & 2 & II & 0 & I & I & I & 4 & I & III \\
\hline I & o & 0 & I & I & 0 & 2 & o & 2 & I & II & 0 & I & I & I & 5 & I & III \\
\hline I & 0 & 0 & I & I & 0 & 2 & 0 & 2 & II & II & 0 & I & I & I & 5 & I & III \\
\hline I & 0 & 0 & I & I & 0 & 2 & 0 & I & II & II & 0 & I & I & I & 5 & I & III \\
\hline
\end{tabular}

The maxilliped (Fig. $6 i$ ) is very similar to the maxilla. The first free segment, however, has patches of small spinules on the posterior (considering the appendage in situ) surface, and a short seta near the distal edge. The other segment is, like that of the maxilla, modified into a strong uncinate claw which lacks secondary claws but has, on either side in the region of greatest curvature, a small, stout denticle.

The last three pairs of mouthparts project ventrally more or less at right angles to this surface of the cephalosome, the maxilla and maxilliped curving distally in towards one another.

A 'postoral protuberance' (Humes, 1953, p. I0I), similar to that present in many copepods, can clearly be seen in lateral view (Fig. $6 b$ ). It is an inflated region, with thin integument and an almost square base, located between the maxillipeds and first swimming legs.

The swimming legs (Figs. 5n, $o, 6 k, l$ ) have all 2-segmented basipods and two rami, each of three segments. The ornamentation is shown in Table 3 and figures. It is interesting to note that the seta on the proximal basipod segment of the first legs is replaced in this position on the other swimming legs by a spine. The outer and distal edges of several of the segments have a row of very small cross-set teeth and/or hairs. The basal

\section{Legend to Fig. 6}

Fig. 6. Conchyliurus cardii, sp.nov., adult female. $a$, dorsal view; $b$, side view; $c$, rostrum; $d$, antennule; $e$, antenna; $f$, mandible; $g$, maxillule; $h$, maxilla; $i$, maxilliped; $j$, mouth complex (abbreviations as for Fig. $3 f$, plus $p g$, position of paragnath); $k$, third swimming leg; $l$, fourth swimming leg; $m$, fifth leg; $n$, sixth leg; $o$, dorsal view of caudal ramus. In $a$ and $b$ spermatophores can be seen. 
plates (lamellae joining the basipods of each pair of legs) possess a rounded lobe, with a tuft of hairs, distally at either end; and the second basipod segment of the first swimming legs has a pointed prominence on the inner side.

The fifth pair of legs (Fig. $6 \mathrm{~m}$ ) is 2-segmented, the basal being completely fused with the thoracic segment and represented only by a widening of this and a seta. The latter is borne on a small papilla, rather more dorsal to the insertion of the free segment than is usually the case (cf. Fig. $6 b$ ). The distal segment is more or less triangular with almost straight sides; about four times as long as wide; with three spines-two more or less terminal, a plumose seta between them, the inner the longer-and one on the outer edge. The terminal margin has a row of close-set spinules, the inner- and outermost rather larger and longer.

The sixth pair of legs (Fig. $6 n$ ) are represented by a pair of projections on the dorsal surface of the genital segment: they are concealed for most of their length by the attached spermatophores. Each has a long feathered spine terminally and another (unornamented) near the base.

The ovisacs (Fig. $6 a$ ) are rather longer than the urosome, and relatively stout; borne laterally from the middle of the genital segment. Each contains about a hundred eggs.

The caudal rami (Fig. 6o) are nearly five-sixths the length of the anal segment and, like the latter, each has a row of very fine teeth ventrally on the distal border. The setae are as illustrated: the two longest with no other ornamentation than a very finely dentate border and a narrow wing for the distal three-quarters of their length.

\section{Dimensions}

Length $\mathrm{r} .83 \mathrm{~mm}$; greatest width $0.48 \mathrm{~mm}$.

\section{Colour}

Colourless, with opaque whitish spots; the ovaries, oviducts and egg-sacs showing rose-pink, and the alimentary canal and region of the fused spermatophores brown.

Male. Unknown.

Biology. The external morphology suggests that this species is an associate, but specimens were never found actually in contact with a Cardium, always in the water surrounding it. A careful search of gills and mantle cavity in both samples of specimens (and one from the Looe-Eddystone Grounds in which no copepods occurred) being negative, it is suggested that future examination of the digestive system might be valuable. In any event, it is unlikely that the

\section{TABLE 4. DIFFERENCES BETWEEN ADULT FEMALES OF CONCHYLIURUS SOLENIS AND C. CARDII}

C. solenis Bocquet \& Stock

I. Accessory hooks on maxilla poorly developed

2. Knob on inner side of basipod $\mathrm{P}_{\mathrm{I}}$ rounded

3. No process on outer distal edge of $\mathrm{P}_{5}$

4. No spines on anal segment

5. Spermatophores not retained on genital segment

6. Specimens found on gills of host
C. cardii, sp.nov.

Accessory hooks on maxilla well developed

Knob on inner side of basipod PI pointed

Large spinule on outer distal edge $\mathrm{P}_{5}$

A line of fine spines on ventral surface of anal segment both near the proximal and on the distal border

Spermatophores retained and fused to genital segment in a complex fashion

Specimens probably in digestive tract of host 
specimens were associated with any other host, since the jars in which they were found contained only this species of Cardium and were covered, immediately after the molluscs were introduced, with fine netting.

Remarks. Bocquet \& Stock (1957) erected the genus Conchyliurus for a species (solenis) which was found on the gills of Solen marginatus near Roscoff. Thanks to the kindness of the latter author, I was able to compare paratypes of this with my specimens. The two are very similar; indeed, it is open to question whether they might be considered host or geographic variations of a single species. However, I have decided to separate mine as a new species by the differences shown in the table, since these seemed both consistent over the range of specimens and of more than phenotypic character. It is hoped that a future comparison of material of both species from a particular locality will determine whether this is the best statement of their relationship.

\section{Family Bomolochidae Wilson, I9I I \\ Bomolochus confusus Stock (I953) \\ B. soleae auct., non Claus}

Occurrence. Adult females and males occurred in the nostrils of the Cod (Gadus callarias Linn.), Pout (G. luscus Linn.), and Whiting (G. merlangus Linn.), all trawled in the Plymouth region. Incidence figures are not given: they vary markedly, depending on whether the hosts are examined immedi- ately on capture or after being brought into the laboratory. However, at sea, nearly every $G$. luscus of moderate size had at least one female-with a maximum of five-in each nostril; in the laboratory, an average figure for $G$. merlangus was one female to every eight hosts; while only one of several $G$. callarias examined had this associate. Males were very rare.

Distribution. British coasts; adults in nostrils of gadoid fishes.

Notes. This species was distinguished by Stock (1953) from Bomolochus soleae Claus mainly on differences in structure of the antennae, maxillipeds and swimming legs-especially the second pair. The specimens I have examined (from the three hosts mentioned) support his distinction, but seem to show minor differences from one another; this suggests that it might be possible to distinguish host-specific forms on morphological grounds.

\section{CYCLOPOIDA: GNATHOSTOMA}

Family CyCLOPIDAE Sars, I9I3

Euryte longicauda Philippi (I843) var. minor T. Scott (1905)

Occurrence. One ovigerous female was found in washings from clinkers and pieces of bored limestone dredged on Asia Shoal, Plymouth Sound, I4 March I955. 
Distribution. Var. minor occurs in the North Sea and English Channel, adults not associated with animals. Typical $E$. longicauda has been recorded from the Arctic Ocean, Atlantic coasts of Europe, British Isles, Mediterranean, Black Sea and Suez Canal; adults littoral.

Notes. Kiefer (1929) includes this form in E. longicauda, but Lang (I946b, pp. I, 2) distinguishes it as a separate species by the relatively longer abdomen and divergent caudal rami. I think Scott's intermediate course is the best until some experimental work has been done on the relationship between these two forms.

\section{CALIGOIDA}

Family LERNAEOCERIDAE Gurney (I933)

Peniculus fistula Nordmann (I832) f. pagelli Delamare Deboutteville \& Nunes (I95I)

Occurrence. (I) One female on the caudal fin of the Common Sea Bream (Pagellus centrodontus de la Roche), hand-lined near the Eddystone Lighthouse ca. I $5 \mathrm{fm}$; June, I954. (2) One female on the pelvic fin, one ovigerous female on the caudal fin of a Spanish Sea Bream (P. erythrinus Linn.) removed from the Plymouth Aquarium; October I954. (This fish had been trawled on the Mewstone Grounds and kept in the Aquarium for some time. It is probable that it was infected before capture.) (3) One female on the caudal fin of $P$. centrodontus, trawled on the Looe-Eddystone Grounds; July 1955.

Distribution. The species is known from the English Channel to the Mediterranean, the adult female on a variety of hosts (Candeias, I955). Forma pagelli occurs through this range, the adult female on the fins of Pagellus sp.

Notes. There seems some difference of opinion about the authorship of the name Peniculus fistula. Nordmann (I832), who described the species, mentions (p. 107) that his specimens had been found by Rudolphi in I8I7. The latter (he says) had sent these, together with unpublished notes and a suggested name (Dirhynchus fistula), to him; he changed the generic name, since it was already in use, but retained the specific for the purpose of his description. According to the Rules of Nomenclature, therefore, Nordmann should be credited with this name.

My specimens agreed closely with the description and figures of f. pagelli given by its authors except that the lengths, even of the ovigerous female, were slightly less. Also, each exhibited a slight curvature of the 'neck' so that the main part of the body was in life held parallel to, and slightly above the surface of the fin to which the head was attached.

This appears to be the first record of the genus in Britain; and of Pagellus centrodontus as host for this form. 


\section{HARPACTICOIDA: OLIGOARTHRA}

Family TISBIIDAE Stebbing (I9I0) sensu Lang (1948)

Tisbe elongata (A. Scott, I896)

Occurrence. All stages from the 'Nauplius V' (that is, a stage corresponding to the one described as Nauplius V for T. furcata by Johnson \& Olson, 1948) to adults were found among the gills of the common lobster (Homarus vulgaris $M$. Edwards) at Plymouth. The copepods were very abundant, averaging nearly fifty per host; and each lobster examined over a period of about a year was infected. In August 1953, also, while working for the Scottish Home Department's Fisheries Laboratory in Aberdeen, I found this species to be very common on lobsters in the Orkneys.

Distribution. British Coasts; adults and stages typically found on gills of H. vulgaris.

Notes. This record is included, although the species has already been noted from Plymouth, both to extend the distribution (by the Orkneys record) and, by emphasizing their abundance and the extent to which developmental stages occur on lobster gills, to support Gurney's (I933, p. 299) suggestion that the species is definitely associated with $H$. vulgaris rather than 'usually free-living' (Humes, I954).

\section{SUMMARY}

The adults of three new cyclopoid copepods are described and figured, namely Micropontius ovoides, gen. et sp.nov., occurring on spatangid echinoids; Lichomolgus leptodermatus, sp.nov., and Conchyliurus cardii, sp.nov., both associated with pelecypod molluscs. Micropontius is made the type of a new family, the Micropontiidae.

Some other copepods, Asterocheres violaceus (Claus), Scottomyzon gibberum (T. \& A. Scott), Pseudanthessius liber (Brady \& Robertson), Bomolochus confusus Stock, Euryte longicauda Philippi var. minor T. Scott and Peniculus fistula Nordmann, are recorded for the first time from the Plymouth region; and mention is also made of Tisbe elongata (A. Scott).

Points of interest in the biology, morphology, systematics and distribution of all these are discussed.

\section{REFERENCES}

Allee, W. C., Emerson, A. E., Park, O., Park, T. \& Schmidt, K., 1949. Principles of Animal Ecology. 837 pp. Philadelphia: Saunders.

Atkins, D., I934. Two parasites of the Common Cockle Cardium edule; a rhabdocoele, Paravortex cardii Hallez and a copepod Paranthessius rostratus (Canu). F. mar. biol. Ass. U.K., Vol. 19, pp. 669-76.

BAER, J. G., I951. Ecology of Animal Parasites. 224 pp. University of Illinois Press. Bocquet, C., I952. Copépodes semi-parasites et parasites des Echinoderms de la Région de Roscoff. Description de Lichomolgus asterinae n.sp. Bull. Soc. zool. Fr., T. 47 , pp. $495-504$. 
Boceuet, C. \& Stock, J. H., 1957. Copépodes parasites d'Invertébrés des côtes de France. I. Sur deux genres de la famille de Clausidiidae commensaux de Mollusques: Hersiliodes Canu et Conchyliurus nov.gen. Proc. Kon. nederl. Akad. Wetensch., Ser. C, Vol. 60, pp. 212-23. (Not seen.)

CandeIas, A., 1955. Peniculus fistula Nordm. on two new hosts Trachurus trachurus (L.) and Trachurus picturatus (Bowd.). Notas Inst. Biol. marit., No. 8.

DAvENPORT, D., 1955. Specificity and behaviour in symbioses. Quart. Rev. Biol., Vol. 30 , pp. $29-46$.

Delamare Deboutteville, C. \& Nunes, L. P., I951. Existence de 'formes biologiques' chez Peniculus fistula (Rudolphi) (Copepoda). Vie et Milieu, T. 2, pp. $448-58$.

GIESBRECHT, W., I899. Die Asterocheriden des Golfe von Neapel und des angrenzenden Meeres-Abschnitte. Faun. u. Flor. Neapel, Monogr. 25, 218 pp.

Gotтo, R. V., 1954. Lichomolgides cuanensis n.g., n.sp., an ascidicolous copepod occurring in Trididemnum tenerum (Verrill). Parasitology, Vol. 44, pp. 379-86.

Gray, P., I933. Mycophilus rosovula n.sp., a notodelphyoid copepod parasitic within $B$. (Botrylloides) leachii Sav. with a description of the nauplius and notes on the habits. F. mar. biol. Ass. U.K., Vol. 18, pp. 523-8.

GuRney, R., 1931. British Fresh-water Copepoda. General Part and Calanoida, Vol. I, 238 pp. London: Ray Society.

— 1933. Notes on some copepods from Plymouth. F. mar. biol. Ass. U.K., Vol. 19, pp. 299-304.

Herdman, W. A. \& SCOTT, A., I896. Report on the investigations carried out in I895 in connection with the Lancashire Sea-Fisheries Laboratory at University College, Liverpool. Section IV: Description of new and rare Copepoda (by A. ScotT). Proc. Lpool. biol. Soc., Vol. 10, pp. 103-77 (134-58).

Humes, A. G., 1953. Ostrincola gracilis C. B. Wilson, a parasite of marine pelycopods in Louisiana (Copepoda Cyclopoida). Tulane Stud. Zool., Vol. I, pp. 99-107.

- I954. Tisbe celata n.sp., a Harpacticoid copepod from the mantle cavity of the Edible Mussel in New Brunswick. F. Fish. Res. Bd Can., Vol. I I, pp. 8I6-26.

Johnson, M. W. \& Olson, J. B., I948. The life history and biology of a marine Harpacticoid copepod, Tisbe furcata (Baird). Biol. Bull., Woods Hole, Vol. 95, pp. $320-32$.

KIEFER, F., I929. Crustacea Copepoda: II. Cyclopoida Gnathostoma. Das Tierreich, Bd. 53,102 pp.

LANG, K., I946a. A contribution to the question of the mouthparts of the Copepoda. Ark. Zool., Bd. 38 A, No. 5 .

- 1946b. Einige für die schwedische Fauna neue marine Cyclopoida Gnathostoma, nebst Bemerkungen über die Systematik der Unterfamilie Cyclopininae. Ark. Zool., Bd. 38A, No. 6.

— I948. Copepoda 'Notodelphyoida' from the Swedish West Coast with an outline on the systematics of the Copepoda. Ark. Zool., Bd. 4OA, No. I4.

LeIGH-ShARPE, W. H., I926. The Herpyllobiidae, a family of Copepoda parasitic on polynoid worms. Parasitology, Vol. 18, pp. 269-76.

- 1933. Second list of parasitic Copepoda of Plymouth with a description of three new species. Parasitology, Vol. 25, pp. I13-18.

NicholLs, A. G., 1944. Littoral Copepoda from South Australia (II): Calanoida, Notodelphyoida, Monstrilloida and Caligoida. Rec. S. Aust. Mus., Vol.8, pp. I-62.

NoRdmann, A., I832. Micrographische Beiträge zur Naturgeschichte der wirbellosen Thiere, Heft 2, 150 pp. Berlin: Reimer. 
Norman, A. M. \& ScotT, T., 1906. Crustacea of Devon and Cornwall. 232 pp. London: W. Wesley.

Sars, G. O., I90I. An Account of the Crustacea of Norway. Vol. 4, Copepoda, Calanoida. Parts I and 2. 28 pp. Bergen Museum.

- 1913-18. An Account of the Crustacea of Norway, Vol. 6, Copepoda, Cyclopoida. 225 pp. Bergen.

SEwell, R. B., I949. The littoral and semi-parasitic Cyclopoida, the Monstrilloida and Notodelphyoida. Sci. Rep. Murray Exped., Vol. 9, No. 2.

STock, J. H., I953. Bomolochus soleae Claus, 1864 and B. confusus n.sp., two hitherto confounded parasitic copepods, with remarks on some other Bomolochus species. Beaufortia, No. 24.

WIIson, C. B., 1932. The Copepods of the Woods Hole Region Massachussetts. Bull. U.S. nat. Mus., No. 158. 635 pp. 